\title{
Comparative performance and water intake of four breeds of broiler chickens fed a popular commercial diet in Kuta
}

Dikko, A. H., Tsado, D. N. and Adama, T. Z.

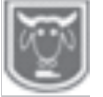

Abstract

Department of Animal Production, Federal University of Technology,

Minna, P.M.B. 65, Niger State, Nigeria

Corresponding author: aliyu.dikko@futminna.edu.ng;07036048131

$\overline{\text { Low protein intake and rapid human population growth in addition constitute a major }}$ problem facing developing countries. To solve this problem of lack of adequate intake of animal products and to increase the output by majority of Nigerians, there is the need to improve poultry and poultry products production by putting a lot of effort in the production of highly reproductive animals becomes very important. The aim of this work is to compare the performance of four breeds of broiler chickens fed a popular commercial Diet in Kuta. One hundred and twenty, day-old chicks of different breeds, and thirty each (Arbor acre, Marshal, Anak, Cobb) were selected and randomly allotted to four treatments with three replicates each in a completely randomized experimental design. Result from the experiment revealed that there was no significance $(P<0.05)$ difference among the treatments in terms of water intake, feed intake body weight gain and feed conversion efficiency. Anak and Cobb breeds has the highest numerical values for the most of the performance indices measured such as average weekly feed intake (1425.60g, 1272.60g), total feed intake (4714.3g, 4509.8g), average weekly water intake $(4046.40 \mathrm{ml}, 4317.00 \mathrm{ml})$, total water intake $(12698.7 \mathrm{ml}$, $14527.6 \mathrm{ml})$, average weekly body weight gain $(298.51 \mathrm{~g}, 348.13 \mathrm{~g})$, and feed conversion ratio (4.87, 3.67). This research show that the Cobb breed have superior performance compare to other breeds on the same feed and under same environmental condition in Kuta. This implies that the production of the four mentioned breeds can perform in Kuta but the feed is more favourable to Cobb breed.

Keywords: Comparative, Performance, breeds, broiler, Chicken

\section{Introduction}

Poultry refers to all domesticated birds rendering economic service to man. It consists of different birds species such as chicken, turkey, pigeons, ducks and others, with chicken being the most important of all species to human diet (Adegbola, 1989) Poultry is one of the important animal protein sources for the ever growing Nigerian Population, thus making significant contribution to the human nutrition and economic development (Obiola , 1992). The poultry industry has in recent years occupied a leading position among agricultural industries in many parts of the world. Poultry meat and eggs serve as important sources of high quality animal protein in those areas of the world that have protein insufficiency (Aduku, 1992). In the past decade, the poultry industry has undergone very rapid development and it is expected that this development will be more pronounced in developing countries than in developed regions of the world (Onu et al., 2000). This is because most developed countries have already reached self-sufficiency, while developing countries are yet to. Intensive poultry production was introduced into Nigeria over fifty years ago and has developed rapidly especially in the last few decades as an important livestock enterprise in the country (FAO, 2000). The rapid expansion of the poultry industry is due to the attractive attributes of poultry which include the ability to adapt easily, high economic value, rapid generation time and a high rate of growth that can result in the production of meat within 7 to 8 weeks and first egg within eighteen weeks of the first 


\section{Comparative performance and water intake of four breeds of broiler chickens}

chick being hatched. Poultry industry contributes more than $75 \%$ of the total livestock production in Nigeria (Hassan, 2010). Feeding is found to be one of the very important aspects of animal production (Abednego et al., 2010). Feeds are chemical substance given to animal for life sustenance and hunger satisfaction. Feeds are chemical composed of substance known as nutrient some of which are protein, minerals, carbohydrates, fats and oils, water and vitamins. These nutrients have definite function in the body. Most natural feeds contain these nutrients in the same proportion and it is important because no matter how much merit an animal has inherited from its ancestors, its maximum capacity for growth and production can be attained only if it is properly nourished, comfortable and healthy. Efficiency with which feeds are utilized is of great importance to poultry farmers. Farmers are naturally attracted and make more profit with feed which when fed to the animal have high conversion efficiency and good quality and quantity product Abednego et.al. (2010).

Feed constitute about $60-65 \%$ of the total cost of production Dafwang (1987). The importance of feed quality cannot be over emphasized as it combines with feed quantity to dictate the level of performance in poultry but millers no longer give due consideration to the quality desired by end users rather they are after quantity to make huge profit from their sales.

Measure of productivity of animals is expressed based on feed conversion efficiency Lacy and Vast (1999). Feed conversion ratio is a composite trait affected by body weight, feed intake and growth rate while being tested. Obviously the lower the conversion the more efficient an animal is. The feed conversion of a flock can be considerable of economic importance to broiler grower.

The aim of this work is to compare the performance of four breeds of broiler chickens fed a popular commercial Diet in Kuta.

\section{Materials and methods \\ Description of area of the study}

The study was carried at the teaching and research farm of Niger college of Agriculture Mokwa, Kuta study Centre. Kuta is characterized by two seasons which are wet (March to October) and dry season (November to March). Kuta lies between latitudes $3^{\circ} 20^{\prime}$ and $7^{\circ} 41^{\prime}$ North of equator and Longitudes $8^{\circ}$ and $11^{\circ} 3^{\prime}$ East of the Greenwich.

\section{Sources of experimental animals}

One hundred and twenty, day-old broiler chickens comprising the four different breeds (30 each) were sourced from different hatcheries were sourced from different commercial hatcheries at Ibadan Oyo State, Nigeria. The breeds sourced were Arbor acre, Marshal, Cobb and Anak. The feed was sourced from commercial feed factory (Sunnah Feed Production Enterprise) along Bosso Road, Bosso local Government Area of Niger State.

\section{Experimental design}

One hundred and twenty broiler chickens comprising the four different breeds (30 each) in a Completely Randomized Design (CRD).. The house was partitioned into four pens in order to have four treatments and each treatment had three replicates with ten birds each. Treatment 1 -Arbor acre breed, 2 - Marshal Breed, 3 - Cobb breed, and 4 Anak breed. The experiment was conducted in two phases, the brooding and the finishing phase.

During brooding, Sunnah starter was measured and fed to the birds in each pen every 24 hours and the left over feed was measured. The same process was done for work to determine the total water intake.

The birds were vaccinated against Newcastle disease (Gumboro and Lasota) between the first week and fourth week 
(Starter phase). During the finishing phase, Sunnah Finisher of same company was used. Standard hygiene measures were maintained throughout the experimental period. The experiment lasted 8 weeks

\section{Data collection}

Data collected was on the following parameters

\section{Water intake}

A known quantity of fresh water was given to the birds at the same time as feed. The water intake was obtained by deducting the quantity of left over from the quantity of water offered.

\section{Average feed intake}

This was obtained by subtracting the quantity of left over feed from the quantity of the feed that was supplied to the birds per day divided by the number of birds for each replicate.

\section{Average body weight gain}

The initial weight of the chicks was taken at the beginning of the experiment by weighing all the chicks in each replicate and dividing by the number of the birds. Subsequently, the average weekly body weight gain was obtained by subtracting the body weight of the previous week from the weight of the present week.

\section{Feed conversion ratio}

This was obtained from the average feed intake per week and the average weight gain per week for each bird.

$\mathrm{FCR}=$

Average feed intake per bird per week

Body weight gain per bird per week

\section{Carcass analysis}

At the end of the experiment, eight birds two from each treatment were used for carcass analysis. The birds were starved for 24 hours after weighing each bird to enable easy evisceration. The bird was slaughtered by cutting the jugular vein using sharp knife. The birds were weighed again to determine the slaughter weight. Hot water was used to defeather the birds by immersing in $60^{\circ} \mathrm{C}$ for 30 seconds in accordance to the procedure of Mounteny (1996). The birds were defeathered immediately and washed in cool water and then weighed. The legs, head, and the neck were cut and crop removed, the abdomen was cut open and the visceral removed. The abdominal fat was removed and wing removed by cutting anteriorly, the drumstick and the thigh was removed to separate the back cut and the breast meat. A cut was made across the rib joints that connect them. Weight of the carcass parts, abdominal parts and the internal organs (visceral) was determined as studied by Adebambo (2012).

\section{Data analysis}

Data collected were subjected to one-way Analysis of Variance (ANOVA) using SPSS (2008) version 16.0. Least significance Difference (LSD) was used to separate the mean at $(\mathrm{P}<0.05)$ significance difference.

\section{Results \\ Average water intake per bird of four different breeds of broiler chickens}

Table 1 shows the weekly average water intake per bird. There was significant $(\mathrm{P}<0.05)$ difference starting from week 1 to week 4 with treatment 4 having the highest water intake values of 634.44, 1097.83, 1461.67 and $2077.33 \mathrm{~mL}$ respectively; at week 5 and 6 , there was no significant difference in the water intake in all the treatments. However, total water intake (TWI) shows a significant $(\mathrm{P}<0.05)$ difference in all the treatments with treatment 4 having the highest value of $14527.6 \mathrm{~mL}$ and treatment 1 having the lowest value of $9724.2 \mathrm{~mL}$ for the total water intake.

Average feed intake per bird (g) of four different breeds of broiler chickens

Table 2 shows the weekly average feed intake. There was a significant $(\mathrm{P}<0.05)$ difference at week 1, 2, 3, 4 and 5 with treatment 3 having the highest value of 


\section{Comparative performance and water intake of four breeds of broiler chickens}

$333.09 \mathrm{~g}$ and $937.80 \mathrm{~g}$ at week 1 and 5 , respectively. There was no significant difference in all the treatments at week 6 though treatment 3 has the highest value. Total feed intake (TFI) show no significant difference in all the treatments.

Average weekly body weight gain per bird (g) of four different breeds of broiler chickens

Table 3 shows the result of the average weekly body weight gain per bird. The
Table show a significant $(\mathrm{P}<0.05)$ difference at week 2, 3, 5 and 6 with treatment 4 having the highest values of $121.33 \mathrm{~g}, 162.67 \mathrm{~g}, 363.49 \mathrm{~g}$ and $348.13 \mathrm{~g}$ at week 1, 2, 5 and 6 respectively. Weeks 1 and 4 show no significant difference. There was a significant $(\mathrm{P}<0.05)$ difference in Total body weight gain (TBWG) among all the treatments with treatment 4 having the highest value of $1631.6 \mathrm{~g}$ and treatment 1 having the least value of $1238.9 \mathrm{~g}$.

Table 1: Average weekly water intake per bird $(\mathrm{ml})$ of four different breeds of broiler chicken

\begin{tabular}{lllllll}
\hline WEEKS & T1 & T2 & T3 & T4 & SEM & LOS \\
\hline 1 & $336.43^{\mathrm{d}}$ & $406.84^{\mathrm{c}}$ & $473.63^{\mathrm{b}}$ & $634.44^{\mathrm{a}}$ & 18.55 & $*$ \\
3 & $700.55^{\mathrm{c}}$ & $728.15^{\mathrm{c}}$ & $865.89^{\mathrm{b}}$ & $1097.83^{\mathrm{a}}$ & 31.03 & $*$ \\
4 & $1236.75^{\mathrm{c}}$ & $1335.96^{\mathrm{ab}}$ & $1496.63^{\mathrm{a}}$ & $1461.67^{\mathrm{ab}}$ & 36.41 & $*$ \\
5 & $1602.67^{\mathrm{c}}$ & $1846.74^{\mathrm{b}}$ & $1858.93^{\mathrm{a}}$ & $2077.33^{\mathrm{a}}$ & 52.79 & $*$ \\
6 & 2382.00 & 3163.70 & 3290.50 & 3372.80 & 332.73 & NS \\
TWI & 3465.80 & 4036.80 & 4046.40 & 4317.00 & 419.99 & NS \\
\hline
\end{tabular}

Mean of the same superscript are not significantly different $(\mathrm{P}<0.05)$, mean of the different superscript are significantly different. (*):Significant NS: not significantT1: Arbor acreT2: Marshall T3: Anak T4: Cobb

TWI: Total Water Intake SEM: Standard error of Mean LOS: Level of Significance

Table 2: Average weekly feed intake per bird (g) of four different breeds of broiler chicken

\begin{tabular}{lllllll}
\hline WEEKS & T1 & T2 & T3 & T4 & SEM & LOS \\
\hline $\mathbf{1}$ & $257.85^{\mathrm{b}}$ & $287.96^{\mathrm{a}}$ & $333.09^{\mathrm{a}}$ & $330.00^{\mathrm{a}}$ & 16.55 & $*$ \\
$\mathbf{2}$ & $443.72^{\mathrm{c}}$ & $510.20^{\mathrm{b}}$ & $576.77^{\mathrm{a}}$ & $585.00^{\mathrm{a}}$ & 15.32 & $*$ \\
$\mathbf{3}$ & $442.25^{\mathrm{c}}$ & $496.75^{\mathrm{b}}$ & $556.24^{\mathrm{a}}$ & $570.83^{\mathrm{a}}$ & 8.76 & $*$ \\
$\mathbf{4}$ & $545.25^{\mathrm{b}}$ & $576.20^{\mathrm{b}}$ & $682.15^{\mathrm{a}}$ & $653.20^{\mathrm{a}}$ & 18.13 & $*$ \\
$\mathbf{5}$ & $653.20^{\mathrm{b}}$ & $784.80^{\mathrm{ab}}$ & $973.80^{\mathrm{a}}$ & $831.10^{\mathrm{ab}}$ & 80.68 & $*$ \\
TFI & 1134.90 & 1213.60 & 1425.60 & 1272.60 & 110.88 & NS \\
\hline
\end{tabular}

Mean of the same superscript are not significantly different $(\mathrm{P}<0.05)$, mean of the different superscript are significantly different. (*): Significant NS: not significantT1: Arbor acreT2: MarshallT3: AnakT4: Cobb

TFI: Total Feed Intake SEM: Standard error of Mean LOS: Level of Significance

Table 3: Average weekly body weight gain per bird (g) of four different breeds of broiler chicken

\begin{tabular}{lllllll}
\hline WEEKS & T1 & T2 & T3 & T4 & SEM & LOS \\
\hline $\mathbf{1}$ & 93.33 & 89.15 & 118.20 & 121.33 & 10.98 & NS \\
$\mathbf{2}$ & $104.00^{\mathrm{b}}$ & $102.91^{\mathrm{b}}$ & $87.70^{\mathrm{b}}$ & $162.67^{\mathrm{a}}$ & 17.43 & $*$ \\
$\mathbf{3}$ & $224.17^{\mathrm{b}}$ & $265.65^{\mathrm{ab}}$ & $306.98^{\mathrm{a}}$ & $210.00^{\mathrm{b}}$ & 23.04 & $*$ \\
$\mathbf{4}$ & 250.00 & 265.71 & 339.68 & 305.00 & 50.56 & NS \\
$\mathbf{5}$ & $341.11^{\mathrm{a}}$ & $330.72^{\mathrm{a}}$ & $341.13^{\mathrm{a}}$ & $363.49^{\mathrm{a}}$ & 15.40 & $*$ \\
$\mathbf{6}$ & $278.81^{\mathrm{a}}$ & $1244.7^{\mathrm{c}}$ & $1461.1^{\mathrm{b}}$ & $1631.6^{\mathrm{a}}$ & 50.30 & $*$ \\
TBWG & $1238.9^{\mathrm{c}}$ & $1244.7^{\mathrm{c}}$ & $1461.1^{\mathrm{b}}$ & $1631.6^{\mathrm{a}}$ & 50.30 & $*$
\end{tabular}

Mean of the same superscript are not significantly different $(\mathrm{P}<0.05)$, mean of the different superscript are significantly different. $(*)$ : Significant NS: not significantT1: Arbor acre T2: MarshallT3: AnakT4: Cobb

TBWG: Total Body Weight Gain SEM: Standard error of MeanLOS: Level of Significance 


\section{Dikko, Tsado and Adama}

Average weekly feed conversion ratio of four different breeds of broiler chickens

Table 4 shows the result of average weekly feed conversion ratio of four different breeds of broiler chickens. The Table shows a significant $(\mathrm{P}<0.05)$ difference among the treatments in weeks 2, 3 and 6 . Also, there was no significant difference in all treatments in weeks 1,4 and 5. There was also significant $(\mathrm{P}<0.05)$ difference in Total feed conversion ratio with $\mathrm{T} 4$ having the best value of 2.70 .

Table 4: Average weekly feed conversion ratio of four different breeds of broiler chicken

\begin{tabular}{lllllll}
\hline WEEKS & TI & T2 & T3 & T4 & SEM & LOS \\
\hline $\mathbf{1}$ & 2.78 & 3.41 & 2.82 & 2.72 & 0.21 & NS \\
$\mathbf{2}$ & $4.23^{\mathrm{ab}}$ & $5.67^{\mathrm{ab}}$ & $7.50^{\mathrm{a}}$ & $3.60^{\mathrm{b}}$ & 1.16 & $*$ \\
$\mathbf{3}$ & $1.98^{\mathrm{b}}$ & $1.89^{\mathrm{b}}$ & $1.85^{\mathrm{b}}$ & $2.82^{\mathrm{a}}$ & 0.26 & $*$ \\
$\mathbf{4}$ & 2.17 & 2.20 & 2.33 & 2.50 & 0.36 & NS \\
$\mathbf{5}$ & 1.93 & 2.40 & 2.93 & 2.30 & 0.31 & NS \\
$\mathbf{6}$ & $4.10^{\mathrm{ab}}$ & $5.67^{\mathrm{a}}$ & $4.87^{\mathrm{ab}}$ & $3.67^{\mathrm{b}}$ & 0.57 & $*$ \\
$\mathbf{T F C R}$ & $3.61^{\mathrm{c}}$ & $3.58^{\mathrm{c}}$ & $3.23^{\mathrm{b}}$ & $2.70^{\mathrm{a}}$ & 0.11 & $*$ \\
\hline
\end{tabular}

Mean of the same superscript are not significantly different $(\mathrm{P}<0.05)$, mean of the different superscript are significantly different. $(*)$ : Significant NS: not significantT1: Arbor acreT2: MarshallT3: AnakT4: Cobb

TFCR: Total Body Weight GainSEM: Standard error of MeanLOS: Level of Significance

\section{Discussion}

The research result showed that the Cobb breeds have the highest value for water intake which means that Cobb breed regulates body temperature better than the other breeds used in the study. This may be attributed to their genetic factor which make the breed adopt better to the environmental condition which is in agreement with the findings of Boyles (2003), that poultry production involves the use of large amount of water; limitation to water intake depress animal performance drastically more than any nutrient deficiency. The Cobb breeds have highest value for body gain (1631.6) and the best feed conversion ratio figure (2.70) which suggest that Cobb breed response to Sunnah feed better than other breeds under Kuta weather condition. Cobb breed utilizes the feeds it consumed more efficiently than the other breeds used though it consumed less feed than the Anak breed. This may be due to the genetic makeup of the Cobb breed which serves as an advantage over other breeds which make them adapt faster to Kuta environmental control than other breed used in the study. This is in agreement with the findings of Abednego et al. (2010). Also, Egena (2009) stated that broiler chickens fed with quality feed and water adlibitum at different growing stages maximizes growth. The Cobb breeds had the best feed conversion ratio over the other breeds used in the study. This finding is in agreement with the result obtained by Lacy and Vast (1999) that the lower the feed conversion efficiency the more efficient the animal. This is most likely due to the breed type and adaptability to the environmental condition of Kuta.

\section{Conclusion}

Based on result obtained from this study, it can be concluded that Cobb breed have good performance over the Arbor acre, Marshall and Anak breeds with respect to feed efficiency, highest water intake, fast growth rate.

Also, the Arbor acre breed showed slow growth, low feed conversion efficiency and less feed and water intake and while Cobb breed under good management could possibly be better for production in Kuta with minimum cost of production due to its low feed intake and fast growth rate. 


\section{Comparative performance and water intake of four breeds of broiler chickens}

\section{Recommendation}

Cobb breed is therefore recommended for production in Kuta area since the breed is more economical in terms of good feed utilization, high water intake and fast growth rate. it is also recommended that further research should be carried out on more breeds.

\section{References}

Adama, T. Z., Ogunbajo, S. A. and Mambo, M. 2007. Feed intake, Growth performance and Nutrient Digestibility of Broiler Chicks fed Diets containing Varying levels of Sorghum Dried Brewer's Grain. International Journal of Poultry Science 6(8): 529-598.

Adebambo, A. O. 2010. Combining the Abilities of Carcass Traits Among Pure and Crossbred Meat Type Chickens. International journal of poultry Science 9 (8): 777- 787.

Adegbola T. A. 1989. A study of Commercial Poultry in Selected Farms in Anambra State, Journal of Animal Production Research,9(2): 61-72.

Aduku, A. O 1992. Practical Livestock Feeds Production in the Tropics. Asekome and co Publishers Zaria Nigeria

Ayorinde, K. L. 1995. The Influence of Genetic Increase in Body Weight on Conformation and Carcass Characteristics of Pearl Guinea fowl. Arch Geflugelk. 60 (30): 99 -102 .

Alaba, A. O. 1990. Fertility and Hatchability of Eggs from Cross breeding Dahlem Red and local chickens. Bachelor of Agriculture Project report, Obafemi Awolowo Univesity, Ile-Ife.
Alibi, R. A. and OSIFO, A. A. 2004. Contributory Role of Animal Production in National Development Procedure of the $9^{\text {th }}$ ASAN Conference 13-16 $6^{\text {th }}$ Sept. Eboyi State University, Abakaliki, Nigeria, 12:177-180.

Boiling, S. D. and Firman, J. D. 1998. Digestible Lysine Requirement of Female Turkeys during the Starter period. Poultry Science 77:547-551.

Boyles, S 2003. Livestock and Water. Beef information, Ohio State University Extension. http://www.ag.ohio-state/edubeef//library/water html.

Dafwang, I. I. 1999. Computers in Livestock Production and Extension Lessons from Israel in Enhancing L i v e s t o c k Production in Nigeria, Book of Proceedings $26^{\text {th }}$ Annual Production of the Nigerian Society of Animal Production: 445-448. University of Ilorin.

Directorate of Poultry Research 2008. Indian Council of Agricultural Research, Department of Agricultural Research and Education, Ministry of Agriculture, Government of $\begin{array}{llllll}\text { I } & n & d & i & a\end{array}$ http://www.pdonpoultry.org/pdp new/. Retrieved August 2017.

Folorunso, O. R. 2012. Performance of Haematology and Carcass Characteristics of Broiler Chicken given $\mathrm{W}$ a t e r fro m different Sources, Nigerian Journal of Animal Production 15:104-113. Arbor Acre Broiler Management Handbook (2014). http://www.aviagen.com. Retrived August 152017

Hassan, B. G. 2010. Digestibility and Nutrient Retention Studies of 
Broiler Starter birds fed Graded Levels of Allamanda carthatica $(\mathrm{L})$. Bachelor of Agriculture Project Report, Dept of Animal Production, Federal University of Technology, Minna.

Keambou, T. C., Manjeli, Y., Tchoumbou, J., Teguia A. and I r o u n e, R . N . 2007 . $\mathrm{Ch}$ aracteris at io $\mathrm{n}$ morphobiometrique des resources Genetique de Poules locales des hautes terres de louest Cameroun. Livestock Research for Rural Development 19:109.

Kemp, C. and Kenny, M. 2003. Feeding the Modern Broiler for More. International Hatchery Practice, (17): $11-13$

Lacy, M. P. and Vast, L. R. 1999. Improving Feed Conversion in Broiler: A Guide for Growers. University of Georgia Comparative Extension Services, College for Agriculture and Environmental Science. Retrieved August 10, 2015 from http://www.irrd.org/irrd19/98/ke am 19107.html.
Obiola F. C. 1992. Guide to poultry Production in the Tropics. http://www.poultryproject.org.ng /poultry management guide/html. Retrieved June 14 July 2017

Ogundipe, S. O. and Sanni, S. A. 2002. Economics of Poultry Production in Nigeria. A training manual NAPRI/ABU Zaria.

Onu, P. N. 2000. Performance and Carcass Characteristics of Broilers Raised on three Difference Litter Materials. Department of Animal Production and Fisheries Management, Ebonyi State University Abakaliki, Ebonyi State (Abstract of Bachelor of Animal Science Project Report).

Payne, W. J. A. 1990. Introduction to Animal Husbandry in Tropics (2):719

Sarojimi, T. R. 1996. Classes of Food. In, Modern Biology: 49-50

Scott, M. L. 2000. Watering System for Heat Distressed Broilers. Poultry Science (71): 178 .

Williams, S. M., Price, S. E. and Siegel, P. B. 2002. Heterosis of growth and Reproductive Traits in Fowl. Poultry Science 81: 1109-1112

Received: $9^{\text {th }}$ October, 2019 Accepted: $15^{\text {th }}$ February, 2020 